\title{
Determinants of Market Outlet Choices of Tef
}

\author{
Addisu Getahun ${ }^{1, *}$, Degye Goshu², Adam Bekele ${ }^{3}$ \\ ${ }^{1}$ Ethiopian Institute of Agricultural Research, Holetta Agricultural Research Center, Addis Ababa, Ethiopia \\ ${ }^{2}$ Department of Economics, Kotebe Metropolitan University, Addis Ababa, Ethiopia \\ ${ }^{3}$ Ethiopian Institute of Agricultural Research, Addis Ababa, Ethiopia
}

Email address:

addisgeta127@gmail.com (A. Getahun), adbk2012@gmail.com (D. Goshu), degyeabgos@gmail.com (A. Bekele)

${ }^{*}$ Corresponding author

\section{To cite this article:}

Addisu Getahun, Degye Goshu, Adam Bekele. Determinants of Market Outlet Choices of Tef. Journal of World Economic Research. Vol. 9, No. 2, 2020, pp. 99-109. doi: 10.11648/j.jwer.20200902.14

Received: October 6, 2020; Accepted: October 22, 2020; Published: November 4, 2020

\begin{abstract}
In Ethiopia, specifically in Dendi district tef is cash crop for majority of the smallholder farmers. and the supply of tef in the study area still can't satisfy the existing market demand and the farmers are not benefited from the market price. This study was aimed at analyzing the factors affecting market outlet choices of tef producers in Dendi district. The study largely uses primary data that were collected through structured and semi-structured questionnaire. Both descriptive statistics and econometric models were used. Multivariate probit model was used to identify the determinants market outlet choices. From descriptive statistics result six tef marketing channels are identified in the district. The multivariate probit model result indicated that educational level of household head, household size, livestock owned, equines owned, land area under tef, distance to the nearest market and current market prices of tef significantly influenced tef producers' choice of alternative market outlets. The probability of choosing wholesalers, consumers, collectors and cooperatives outlets are $64.4 \%, 41.6 \%, 39.1 \%$ and $51.1 \%$, respectively. Wholesalers is the most likely chosen market outlet while collectors are the less likely chosen market outlet. The joint probabilities of the households to jointly choose the four market outlets was $4.1 \%$ which is lower than the likely of not choosing all market outlets which is $5.2 \%$. Therefore, strategies aiming at promoting tef producers' marketing and outlet choices should focus on strengthening the technical skills, resource base, infrastructural and institutional capacity of smallholder farmers.
\end{abstract}

Keywords: Smallholders, Multivariate Probit, Tef, Market Outlet, Dendi

\section{Introduction}

\subsection{Background of the Study}

Since the majority of population in developing countries like Ethiopia is agrarian and the agriculture sector is the main source of their livelihoods, participation of these households in agricultural markets is anticipated to positively affect their wellbeing. In Ethiopia the agricultural sector contributes $36.7 \%$ of overall GDP and $70 \%$ of foreign exchange earnings. The sector provides employment for $72.7 \%$ of the population and is a means of livelihoods for about $83 \%$ of the rural population $[1,2]$. In the agricultural sector, cereals cover about $80 \%$ of the total grain crop area (9.97 million hectares) and contribute about $87 \%$ (23.1 million tons) of the grain production. Among cereals, tef (Eragrostis tef) stands first in terms of land area, followed by maize and wheat [3].
Ethiopia is the center of both origin and diversity for tef [4].

$T e f$ is a staple food and one of the most important crops for generating farm income, cultural heritage, national identity and nutritional security. Tef has the highest market value among all cereals grown and it is a source of cash income for Ethiopian small farm households. It is the second most important cash crop after coffee and generating almost 500 million USD income per year for local farmers [5]. Compared to other staples, the price of tef has increased at faster rate in recent years, hence the price gap between tef and other staples is widening. Brokers in regional markets work as agents of traders and negotiate prices and grade levels with farmers who often have limited bargaining power [6]. However, smallholder farmers are not benefited from price increment due to market problems.

Market access has been identified as one of the critical factors influencing the performance of smallholders' 
agriculture in developing countries [7]. Marketing plays an important role in agricultural production and accessibility of the market for commodities allows specialization of production, which in turn increases productivity and efficiency. Well-functioning market leads to efficient allocation of scarce resources and maximization of the general welfare of the society. Proper functioning market will only occur when enough markets and efficient market outlets exist for the sale of produced output and no single entity can individually influence the price [8].

The study area is found in West Shewa zone of Oromia region, central Ethiopia. West Shewa zone is potential area of tef production in central Ethiopia. The land area covered by tef in the zone was 205,573.1 hectares and from it $3,808,745.7$ quintals of tef was produced during 2015/16 production year. The productivity of tef in the zone was $(18.53 \mathrm{qt} / \mathrm{ha})$ is higher than the national and regional average which was (15.6 qt/ha) [3]. There is lack of information in terms of identifying the factors affecting market outlet choices of tef producer particularly in Dendi district West Shewa zone of Oromia region, one of the potential areas of tef production in Central Ethiopia. Such information is essential for making knowledge-based decision that are geared towards improving market participation of smallholder farmers in tef.

Various studies on market outlet choices [9-12] were conducted in different regions of Ethiopia on pulse and vegetable crops. However, the past studies did not address the market outlet choice problems of tef. Since tef is the most economically and socially crucial crop, there is a strong need to address the prevailing information gap and contribute to proper understanding of the demographic, socio-economic, institutional and infrastructural determinants of market outlet choices of smallholder farmers in Dendi district. So, this study identifies factors affecting market outlet choices of tef producers and address the knowledge gap in the study area.

\subsection{Objectives of the Study}

The general objective of this study was to identify factors affecting market outlet choices of tef in Dendi district of Oromia, Central Ethiopia whereas the specific objectives are:

1. To identify the tef marketing channels in the study areas;

2. To identify factors affecting tef market outlet choices of tef.

\section{Research Methodology}

\subsection{Description of the Study Area}

Dendi district is located in Oromia regional state of West Shewa zone, Central Ethiopia. Dendi district lies at about 80 $\mathrm{km}$ west of Addis Abeba. The district is geographically situated within $038^{0} 10^{\prime} 54^{\prime \prime} \mathrm{E}$ longitude and $9^{\circ} 01^{\prime} 16^{\prime \prime} \mathrm{N}$ latitude and at an altitude of 2200 meter above sea level. Dendi district is bordered on the south by Dawo and Wenchi, on the west by Ambo and Elfeta, on the north by Jeldu, and on the east by Ejersa Lafo districts (Figure 1). The district has a total of 38 kebeles, of which, 35 are rural and 3 are urban. According to [13] the total population of the study district is 200715, male and female households constitute $85.6 \%$ and $14.4 \%$, respectively.

The total area coverage of the district is 79,936.29 hectares. Dendi district is endowed with favorable climatic and natural resource conditions that can grow diverse annual crops for household consumption and for the market. The district has two agro-ecologies; highland (29\%) and midland (71\%), indicating that the district is dominated by midland agro-ecology. In the district, mixed farming system of both crops and livestock is common economic activity [13]. Cereal crops grown in the district includes: tef, wheat, barley, maize and sorghum. The district is known for its highest production of tef. Tef production takes the lion share and main source of income generation to farmers in the district. Around the study area, there are three commonly known tef marketing centers, namely, Ginchi, Kidame and Asgori.

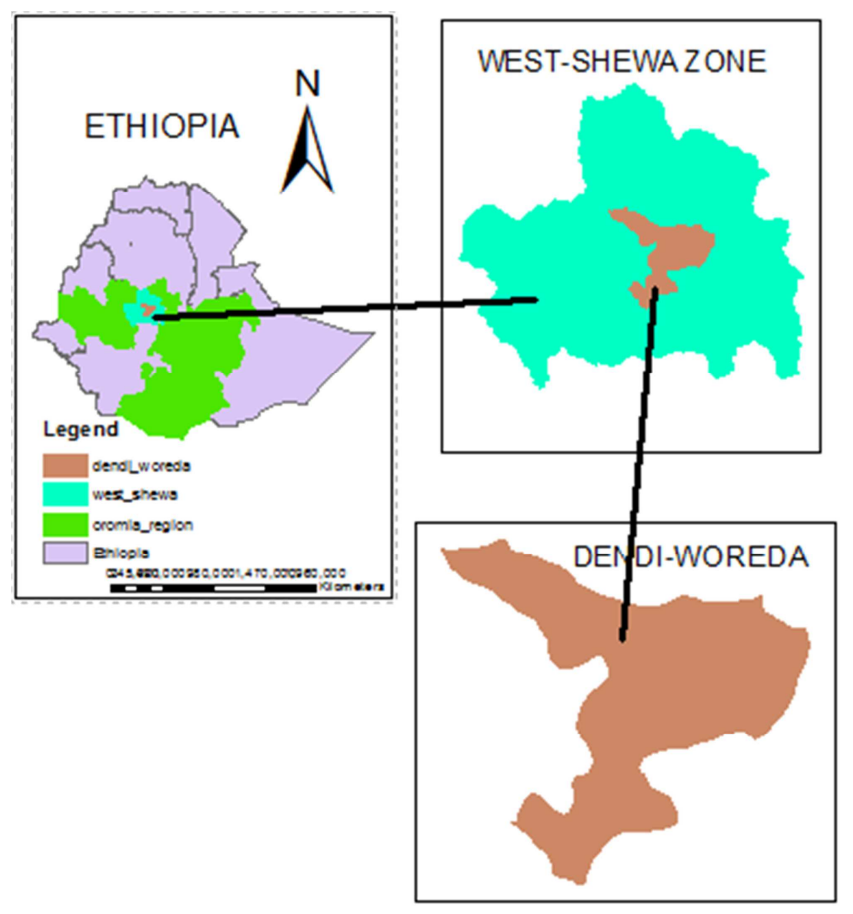

Figure 1. Location of the study area.

\subsection{Data Types, Sources and Methods of Data Collection}

Both primary and secondary data were used for this study. Primary data were collected from randomly selected tef producers in five rural kebeles, from tef traders and consumers in the district. The primary data collected from farmers were focusing on factors affecting market outlet choices, such as: demographic characteristics of the household, farming experience, livestock owned (TLU), equines owned (TLU), size of land allocated to tef production, distance to the nearest market, access to credit service, frequency of extension contact, non/off-farm income, current market price of tef and cooperative membership. Moreover, the interview schedule for tef traders includes: 
demographic characteristics of traders, capital requirements, buying and selling activities. The interview schedule for consumers includes: demographic characteristics of consumers, source of income and buying activities.

Primary data were collected by structured and semistructured questionnaires and by well-trained enumerators using Computer Aided Personal Interview (CAPI). In addition, checklist was used to generate data through group discussion. Secondary data on socio-economic information of the district, trends in agricultural production, opportunities and challenges of tef production and marketing were taken by reviewing secondary sources from published and unpublished documents of governmental institutions. Beside to these information, journals and websites were visited to generate relevant secondary information focusing on the objectives of the study.

\subsection{Sampling Procedure and Sample Size Determination}

The target populations for this study were smallholder tef producers, tef traders and consumers in Dendi district. Purposive and two stage random sampling procedure was used for the selection of sample household heads. Dendi district was selected purposively since it is the potential area of tef production in West Shewa zone, Central Ethiopia. In the first stage, five tef producing kebeles; namely, Dano Ejersa Gibe, Wamura Sako, Lokloka Abba, Werka Werabu and Yubdo Legabatu were selected randomly from a total of 24 tef producing kebeles of the district.

In the second stage, from the total of 2425 households in the selected five kebeles, 210 sample household heads were selected randomly, using probability proportionate to size of tef producer households in the kebeles. The total sample size $(n=210)$ was determined following a simplified formula provided by Yemane [14]. Accordingly, the required sample size at $95 \%$ confidence level with degree of variability of $5 \%$ and level of precision equal to $6.6 \%$ were used to obtain a sample size required to represent the true population.

$$
n=\frac{\mathrm{N}}{1+\mathrm{N}(\mathrm{e})^{2}}
$$

Where: $\mathrm{n}=$ sample size, $\mathrm{N}=$ population size (sampling frame) and $\mathrm{e}=$ level of precision.

In addition, data were also collected from 20 tef traders. Census survey was conducted to obtain relevant information regarding tef traders. Similarly, data were also collected from 32 consumers in Dendi district.

\subsection{Methods of Data Analysis}

Two types of data analysis methods, namely descriptive statistics and econometric models were used for analyzing the data collected from smallholder tef producers, tef traders and consumers.

\subsubsection{Descriptive Statistical Analysis}

Descriptive statistical analysis method such as mean, proportions, percentages, and standard deviations were used in the process of examining and describing farm households' demographic characteristics, resource ownership, institutional and infrastructural service, production characteristics, tef marketing channels, financial asset and demographic characteristics of tef traders and consumers.

\subsubsection{Econometric Analysis}

A Multivariate probit model (mvprobit) was used to identify factors affecting household choices of tef market outlets.

To investigate factors affecting market outlet choice of sample households Multivariate probit model was used. Multivariate probit model simultaneously models the influence of a set of explanatory variables on choice of market outlets, while allowing for the potential correlations between unobserved disturbances as well as the relationship between the choices of different market outlets [15]. In the study area, smallholder tef producers face different choices of market outlets like: wholesalers, consumers, collectors and cooperatives. Thus, in this study since tef is one of the cash crops that enables producers to choose more than one outlet that are not mutually exclusive to get better price. Considering the possibility of simultaneous choices of outlets and the potential correlations among these market outlet choice decisions multivariate probit model (mvprobit) was appropriate to capture household variation in the choice of market outlets and to estimate several correlated binary outcomes jointly.

The observed outcome of market outlet choice can be modeled by the following random utility formulation. Consider the $i^{\text {th }}$ farm household $(i=1,2 \ldots \ldots . N)$, facing a decision problem on whether or not to choose available market outlets. Let $U_{o}$ represent the benefits to the farmer who chooses wholesalers and let $\mathrm{U}_{\mathrm{k}}$ represent the benefit of farmer to who choose the $\mathrm{K}^{\text {th }}$ market outlets: where $\mathrm{K}$ denotes choices of wholesalers $\left(\mathrm{Y}_{1}\right)$, consumers $\left(\mathrm{Y}_{2}\right)$, collectors $\left(\mathrm{Y}_{3}\right)$ and cooperatives $\left(\mathrm{Y}_{4}\right)$. The farmers decide to choose the $\mathrm{K}^{\text {th }}$ market outlet if:

$$
Y_{i k}^{*}=U_{k}^{*}-U_{o}>0
$$

The net benefit ( $Y_{i k}^{*}$ ) that the farmer derives from choosing a market outlet is a latent variable determined by observed explanatory variable (Xi) and the error term $\left(\varepsilon_{\mathrm{i}}\right)$ :

$$
Y_{i k}^{*}=x_{i}^{\prime} \beta_{k}+\varepsilon_{i}\left(k=Y_{1}, Y_{2}, Y_{3}, Y_{4}\right)
$$

Where, in this study, $Y_{1}=$ wholesalers, $Y_{2}=$ consumers, $Y_{3}=$ collectors and $Y_{4}=$ cooperatives. Using the indicator function, the unobserved preferences in the above equation translates into the observed binary outcome equation for each choice as follows:

$$
Y_{i k}=\left\{\begin{array}{c}
1 \text { if } x_{i}^{\prime} \beta_{k}+\varepsilon_{i}>0, \\
0 \text { if } x_{i}^{\prime} \beta_{k}+\varepsilon_{i} \leq 0
\end{array}\left(K=Y_{1}, Y_{2}, Y_{3} Y_{4}\right)\right.
$$

Where: $x^{\prime}$ is a vector of explanatory variables;

$\beta$ denotes the vector of parameters to be estimated; and

$\varepsilon$ are random error terms distributed as multivariate normal distribution with zero mean and unitary variance. 
$Y_{i}$ is a set of binary dependent variables such that: $Y_{1}=$ wholesaler, 1 for the farmer who choose wholesalers, 0 otherwise; $\mathrm{Y}_{2}=$ consumer, 1 for the farmer who choose consumers, 0 otherwise; $\mathrm{Y}_{3}=$ collector, 1 for the farmer who choose collectors, 0 otherwise and $\mathrm{Y}_{4}=$ cooperative, 1 for the farmer who choose cooperatives, 0 otherwise.

In multivariate probit model, where the choice of several market outlets is possible the error terms jointly follow a multivariate normal distribution (MVN) with zero conditional mean and variance normalized to unity (for identification of the parameters) where $\left(\mu_{y 1}, \mu_{y 2}, \mu_{y 3}, \mu_{y 4}\right) M V N \sim(0, \Omega)$ and the symmetric covariance matrix $\Omega$ is given by:

$$
\Omega=\left[\begin{array}{cccc}
1 & \rho_{y 1 y 2} & \rho_{y 1 y 3} & \rho_{y 1 y 4} \\
\rho_{y 2 y 1} & 1 & \rho_{y 2 y 3} & \rho_{y 2 y 4} \\
\rho_{y 3 y 1} & \rho_{y 3 y 2} & 1 & \rho_{y 3 y 4} \\
\rho_{y 4 y 1} & \rho_{y 4 y 2} & \rho_{y 4 y 3} & 1
\end{array}\right]
$$

Particular interest are off-diagonal elements in the covariance matrix, which represents the unobserved correlation between the stochastic components of the different type of outlets. This assumption means that the above equation generates a MVP model that jointly represents decision to choose particular market outlet. This specification with non-zero off-diagonal elements allows for correlation across error terms of several latent equations, which represents unobserved characteristics that affect the choice of alternative market outlets. Following the form used by Cappellari and Jenkins [16] the log-likelihood function associated with a sample outcome is given by:

$$
\ln L=\sum_{i=0}^{N} \omega_{i} \ln \Phi\left(\mu_{i}, \Omega\right)
$$

Where $i$ is an optional weight for observation $i$, and $\Phi$ is the multivariate standard normal distribution with arguments $\mu_{\mathrm{i}}$ and $\Omega$, where $\mu_{\mathrm{i}}$ can be denoted as;

$$
\begin{array}{r}
\mu_{i}=\left(k_{i 1} \beta_{1} x_{i 1}, k_{i 2} \beta_{2} x_{i 2}, k_{i 3} \beta_{3} x_{i 3}\right), \text { While } \Omega_{\mathrm{ik}}=1 \text { for } \mathrm{j}=\mathrm{k} \text { and }(7) \\
\Omega_{\mathrm{jk}}=\Omega_{\mathrm{kj}}=k_{i j} k_{j k} \rho_{j k} \text { for } j \neq k, k= \\
1,2,3 \ldots \text { With } k_{i k}=2 y_{i k}-1
\end{array}
$$

\subsection{Hypothesis and Definition of Variables}

In order to identify factors affecting market outlet choices of tef producers, the following dependent and independent variables were defined and hypothesized in the study.

Market outlet choice (MKTOCH): It is a categorical binary dependent variable measured by a choice of outlets defined and measured as binary outcome. The multivariate probit has a set of categorical binary dependent variables $\mathrm{Y}_{\mathrm{i}}$, such that: $\mathrm{Y}_{1}=$ wholesalers; $\mathrm{Y}_{2}=$ consumers; $\mathrm{Y}_{3}=$ collectors; and $\mathrm{Y}_{4}=$ cooperatives for the farmer who chooses wholesalers,

\begin{tabular}{|c|c|c|c|c|c|c|}
\hline \multirow{2}{*}{ Variables } & \multirow{2}{*}{ Type } & \multirow{2}{*}{ Measurement } & \multicolumn{4}{|c|}{ Expected effect } \\
\hline & & & Wholesalers & Consumers & Collectors & Cooperatives \\
\hline SEXHH & Dummy & 1 if the household head is female; 0 otherwise & + & + & - & + \\
\hline EDUHH & Continuous & Grades completed & + & - & - & + \\
\hline HHSIZE & Continuous & No of household & + & - & - & - \\
\hline FREXP & Continuous & No of years & + & - & - & + \\
\hline LIVOWN & Continuous & TLU & + & - & + & + \\
\hline NEQUIO & Continuous & TLU & + & + & - & + \\
\hline MRKTDIS & Continuous & Minutes of walk & - & + & + & - \\
\hline FRQEXT & Discrete & Frequency & + & - & - & + \\
\hline NONFAR & Continuous & ET Birr & - & - & + & - \\
\hline CURPRT & Continuous & ET Birr per quintal & + & - & - & + \\
\hline
\end{tabular}
consumers, collectors, and cooperatives, respectively. Definition and hypothesis of independent variables are indicated on Table 1 below.

Table 1. Definition and hypothesis of independent variables.

\section{Result and Discussion}

\subsection{Demographic and Socio-economic Characteristics of Sample Households}

As indicated in Table 2, out of total sample respondents, 172 $(81.9 \%)$ were male-headed and 38 (18.1\%) were female-headed households. Regarding cooperative membership, 104 (49.5\%) of the sample households were members of cooperatives and 106 $(50.4 \%)$ were not organized under cooperatives whereas 57 (27.1\%) of the sample households has access to credit and 153 (72.8\%) doesn't have credit access.
Table 2. General characteristics of sample tef producers (dummy variables).

\begin{tabular}{lll}
\hline Variables & Frequency & Percent \\
\hline Sex of household head & & \\
Female & 38 & 18.1 \\
Male & 172 & 81.9 \\
Cooperative membership & & \\
Yes & 104 & 49.52 \\
No & 106 & 50.48 \\
Access to credit & & \\
Yes & 57 & 27.14 \\
No & 153 & 72.85 \\
\hline
\end{tabular}

Source: Own survey result, 2017.

Accordingly, with regards to the educational level of sample household heads, the average number of formal 
schooling completed was 4.17 years with a standard deviation of 3.61. The average household size of sample respondents in adult equivalent was 4.40 with standard deviation of 1.5 (Table 3 ). The average farming experience of sample respondents that an individual continuously engaged in tef production was 18.35 years with standard deviation of 7.3 (Table 3).

Table 3. General characteristics of sample tef producers (continuous variables).

\begin{tabular}{|c|c|c|c|c|}
\hline Variable & Mean & Std. Dev. & Min & Max \\
\hline Education level (years of formal schooling) & 4.17 & 3.61 & 0 & 15 \\
\hline Household size (Adult equivalent) & 4.40 & 1.58 & 1 & 8.15 \\
\hline Farming experience (No of years) & 18.35 & 7.33 & 4 & 37 \\
\hline Livestock owned (TLU) & 4.18 & 2.30 & 0 & 9.85 \\
\hline Number of equines owned (TLU) & 1.20 & 0.94 & 0 & 3 \\
\hline Size of land under tef production (Hectare) & 1.15 & 0.59 & 0.2 & 2.5 \\
\hline Frequency of extension contact (Count) & 7.559 & 5.772 & 0 & 18 \\
\hline Non/off-farm income (ET Birr) ${ }^{a}$ & 3.899 & 5.106 & 0 & 16 \\
\hline Current market prices of tef (ET Birr/qt) ${ }^{a}$ & 1.834 & 1.843 & 1.835 & 0.202 \\
\hline
\end{tabular}

Source: Own survey result, 2017.

Note: 'a' indicates the amount of non/off-farm income obtained and current market prices of tef in thousands (000) of ETB.

\subsubsection{Resource Ownership of Sample Households}

Ownership of physical resources is an important factor that affects alternative market outlet choices.

\section{Land ownership}

The analysis of survey data depicts that the average total land size owned by the sample households was 1.8 hectare with standard deviation of 1.3 . The average area of land under tef production by sample households was 1.2 hectare with standard deviation of 0.6 (Table 3 ). The minimum and maximum land allocated for tef production was 0.2 and 2.5 hectares, respectively.

Livestock ownership

In the district, mixed crop and livestock farming system is dominantly used by farm households. Livestock resources are useful in the livelihoods of smallholders, oxen are the major contributors to crop production by serving as a draft power. The average livestock owned by sample households excluding equines was 4.2 TLU with a standard deviation of 2.3 (Table 3 ).

Equine ownership

In the study areas equines are used as a means of transport by smallholder farmers. Equines provide transport services for farm inputs from market to home, harvested farm produce from field to threshing center and for marketing of output. Out of total sample households 57 (27.1\%) of them do not own equines. The rest $73(34.7 \%), 62(29.5 \%)$, and $18(8.5 \%)$ of sample households owned one, two and three equines, respectively.

Off/Non-farm income activities

The major off/non-farm income generating activities in which sample households were participating in the study areas includes: animal cart, daily laborer, remittance and petty trade. The mean cash income obtained from off/nonfarm income was 3899 ET Birr with standard deviation of 5106 (Table 3).

\subsubsection{Institutional and Infrastructural Services of Farm Households}

Sample households in the study areas received different institutional service regarding tef production and marketing. Frequency of extension contact

Agricultural extension service provision on production and marketing have direct influence on the production and marketing behavior of the farmers. The average frequency of extension service provided for sampled households was 7.5 day/year with standard deviation of 5.7 (Table 3).

Distance from the nearest market

The distance from home to the nearest market place where farmers sold their tef produce was an average of 67 minutes of walk with standard deviations of 26.8 (Table 3). The minimum and maximum distance that tef producing households travel to the nearest market were 30 and 150 minutes, respectively.

\subsection{Demographic and Socio-economic Characteristics of Tef Traders}

\subsubsection{Demographic Characteristics of Tef Traders}

Demographic characteristics of sample tef traders were summarized in terms of sex, marital status, age, educational level and household size. Out of 20 sampled traders $8(40 \%)$ of them are collectors and $12(60 \%)$ of them are wholesalers. As indicated in Table 4, out of the total sample traders, 17 (85\%) were male-headed and $3(15 \%)$ were female-headed. Regarding marital status of sample traders $2(10 \%)$ and 18 $(90 \%)$ were single and married, respectively.

Table 41. Distribution of sample traders by sex and marital status.

\begin{tabular}{lll}
\hline Variables & Number & Percent \\
\hline Sex Female & 3 & 15 \\
Male & 17 & 85 \\
Marital status Single & 2 & 10 \\
Married & 18 & 90 \\
\hline
\end{tabular}

Source: survey result, 2017.

As indicated in Table 5, the mean age of sample tef traders were 42 years with standard deviation of 8.759 . The average 
household size of sample trades was 4.8 persons with standard deviation of 2.667. Concerning educational status of tef traders, the average number of years of schooling completed was 5.35 years with a standard deviation of 3.731 .

Table 52. Distribution of sample traders by age, household size and education.

\begin{tabular}{lll}
\hline Variables & Mean & Standard deviation \\
\hline Age & 42 & 8.759 \\
Household size & 4.8 & 2.667 \\
Educational level of traders & 5.35 & 3.731 \\
\hline
\end{tabular}

Source: survey result, 2017.

\subsubsection{Financial Assets of Tef Traders}

Initial working capital: The result indicated that the mean initial working capital of sample tef traders was 19627.5 ET birr with standard deviation of 10138.8. The minimum and maximum initial capital of tef traders were 12000 ET birr and 50000 ET birr, respectively.

Current working capital: The result revealed that the mean working capital of sample tef traders was 57875 ET birr with standard deviation of 105663.3. The minimum and maximum working capital of sample tef traders were 20000 ET birr and 500000 ET birr, respectively.

Table 63. Financial asset ownership of sampled traders.

\begin{tabular}{lllll}
\hline Description & Mean & Std. dev. & Min & Max \\
\hline Initial working capital & 19627.5 & 10138.84 & 12000 & 50000 \\
Current working capital & 57875 & 105663.3 & 20000 & 500000 \\
\hline
\end{tabular}

Source: survey result, 2017.

\subsection{Demographic Characteristics of Sample Consumers}

Demographic characteristics of sampled tef consumers were summarized in terms of sex, marital status, educational level and household size. The sampled consumers earn their income from different sources and the purchasing power of the consumer depends on his/her monthly income. The survey results indicated in Table 7, shows that the majority of sampled consumers were females; $21(65.6 \%)$ and the remaining $11(34.4 \%)$ were males. This shows that females' involvement in the tef purchasing activities was high. Regarding marital status of consumers, the majorities 28 $(87.5 \%)$ were married and $4(12.5 \%)$ were single.

Table 74. Distribution of sample consumers by sex and marital status.

\begin{tabular}{lll}
\hline Variables & Number & Percent \\
\hline Sex Female & 21 & 65.62 \\
Male & 11 & 34.38 \\
Marital status Single & 4 & 12.5 \\
Married & 28 & 87.5 \\
\hline
\end{tabular}

Source: survey result, 2017.

As indicated in Table 8, the mean household size of consumer was 4.5 persons with standard deviation of 2.676 . Regarding the educational level of consumers, the survey result shows that the mean number of years of schooling completed was 6.8 with a standard deviation of 3.486 .
Table 85. Distribution of sample consumers by household size and education.

\begin{tabular}{lll}
\hline Variables & Mean & Standard deviation \\
\hline Household size & 4.5 & 2.676 \\
Educational level & 6.81 & 3.486 \\
\hline
\end{tabular}

Source: survey result, 2017.

\subsection{Tef Marketing Outlets}

The survey result indicated that sample households in the study area sold their tef produce at different marketing center. The sample households sold varying proportion of their tef output to different market outlets in the district which include: wholesalers, consumers, collectors and cooperatives. Result of the survey in Table 9, indicated that 133 (63.3\%) of households sold their tef output to wholesalers whereas 81 $(38.5 \%), 87(41.4 \%)$ and $104(49.5 \%)$ of the sample households sold their tef output to collectors, consumers and cooperatives, respectively.

Table 9. Market outlet choices of tef producers in the study area.

\begin{tabular}{lll}
\hline Market outlets & Number of sellers & Proportion (\%) \\
\hline Wholesalers & 133 & 63.33 \\
Consumers & 87 & 41.43 \\
Collectors & 81 & 38.57 \\
Cooperatives & 104 & 49.52 \\
Total & 405 & 192.85 \\
\hline
\end{tabular}

Source: survey result, 2017.

The survey result showed that out of total output sold in the market wholesalers, consumers, collectors and cooperatives purchased $43.3 \%, 15.6 \%, 17.5 \%$ and $23.5 \%$ of tef produce, respectively (Figure 2). From the context of survey result, Smallholder farmers and market outlets in tef marketing were discussed below and the result of factors affecting tef market outlet choice of tef producer were discussed in econometric analysis result.

Smallholders: Farmers start from input preparation to produce tef for the purpose of cash earnings and household consumption. Tef producers in Dendi district supply their produce to the market by using equine transport and sold to wholesalers, collectors, consumers and cooperatives.

Wholesalers: wholesalers were the participants of the marketing system those who buy large volume tef with relative to other market outlets. Wholesalers in the study area buy tef from farmers, collectors and cooperatives. They sell the purchased tef to processors (hotels, restaurants and millers), consumers and to wholesalers at central market (Addis Ababa).

Collectors: Collectors are marketing actors those who assemble tef from farmers and deliver to wholesalers and also sell to consumers in the district. Some collectors in the district do not have sufficient capital to purchase tef, they operate with advances that they received from wholesalers.

Consumers: Consumers are those households who engaged in different income generating activities and purchase tef grains for consumption purposes from farmers, collectors or wholesalers. 
Cooperatives: Cooperatives in the study area perform multi-functions. Cooperatives play a crucial role in supplying agricultural inputs (like: improved seed, fertilizer and herbicide) to the farmers and also involve in purchasing of agricultural output from farmers and resale it to wholesalers and seed enterprise. In addition, cooperatives provide in-kind credit (e.g. improved seed) for seed multiplication and also serve storage facility for the members.

Tef marketing channels

The analysis of marketing channels was intended to know the alternative routes that the tef output flows from producers to final destination. Marketing channels are alternative routes of product flows from producers to consumers [17]. Six alternative tef marketing channels through which tef produce flows to the final consumers were identified in the study areas.

Channel 1: Producers $\Rightarrow$ Consumers

Channel 2: Producers $\Rightarrow$ Collectors $\Rightarrow$ Consumers

Channel 3: Producers $\Rightarrow$ Collectors $\Rightarrow$ Wholesalers $\Rightarrow$ Processors $\Rightarrow$ Consumers

Channel 4: Producers $\Rightarrow$ Wholesalers $\Rightarrow$ Wholesalers at central market (Addis Abeba) $\Rightarrow$

Processors $\Rightarrow$ Consumers

Channel 5: Producers $\Rightarrow$ Cooperatives $\Rightarrow$ Wholesalers $\Rightarrow$ Consumers

Channel 6: Producers $\Rightarrow$ Cooperatives $\Rightarrow$ Seed enterprise $\Rightarrow$ Tef producing farmers

These market channels with the proportion of tef outputs flow through the channels are indicated in the following Figure 2.

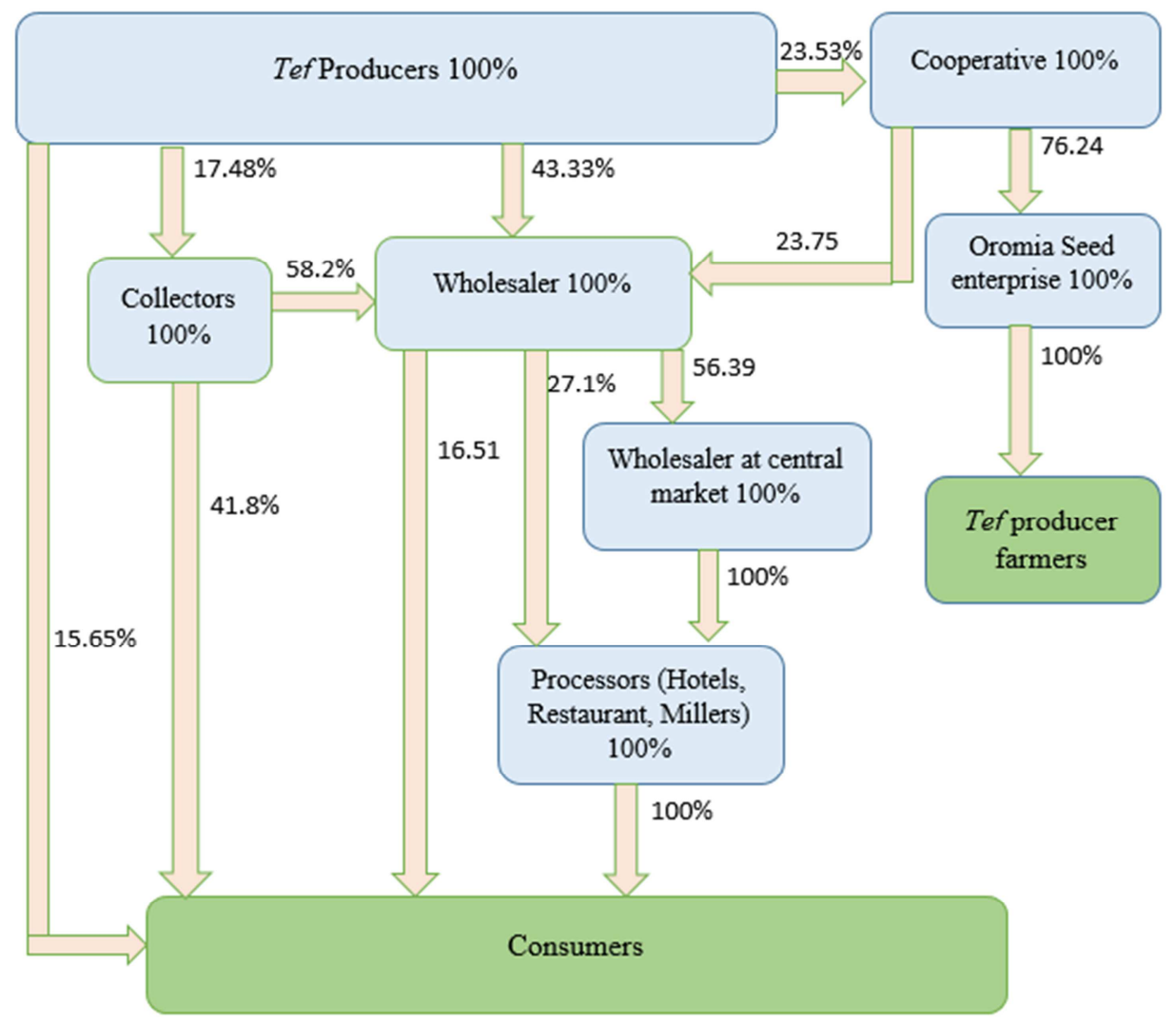

Source: own sketch (survey result, 2017)

Figure 2. Tef marketing channels.

\subsection{Econometric Results}

The data management for the study was done by using SPSS whereas analysis of the survey data was carried out by using STATA 15.

The multivariate probit model is used to estimate several correlated binary outcomes jointly. In this study the decisions of tef producers choosing wholesalers, consumers, collectors and cooperatives outlets are correlated. Since the decisions are binary the multivariate probit model was found to be appropriate for jointly predicting these four outlet choices on an individual-specific basis and the parameter estimates are simulated maximum likelihood (SML) estimators. Thus, an econometric approach was employed to test effects of the explanatory variables on the selection of a particular market outlet. The Wald $\mathrm{chi}^{2}(44)=177.63$ is significant at $1 \%$ significance level, which indicates that the subset of coefficients of the model is jointly significant and that the explanatory power of the variables included in the model is acceptable. In this study samples are drawn 100 times to increase the accuracy, since higher number of draws increases the precision level. The results of likelihood ratio test in the model shows that likelihood ratio test of $\mathrm{chi}^{2}(6)=$ 45.61 , Prob $>\mathrm{chi}^{2}=0.000$ is statistically significant at $1 \%$ 
significance level, indicating the null that choices of the four market outlets is independent is rejected and there are significant joint correlations for two estimated coefficients across the equations in the models (Table 10). The likelihood ratio test of the null hypothesis of independency between the market outlet decision $\left(\rho_{21}=\rho_{31}=\rho_{41}=\rho_{32}=\rho_{42}=\rho_{43}=0\right)$ was significant at $1 \%$. Therefore, the null hypothesis that all the $\rho$ (Rho) values are jointly equal to zero is rejected, showing the goodness-of-fit of the model. So, there are differences in market outlet selection behavior among smallholders marketing tef, which are reflected in the likelihood ratio statistics.

Separately considered, the $\rho$ values $\left(\rho_{i j}\right)$ indicate the degree of correlation between each pair of dependent variables. The $\rho_{21}$ (correlation between the choice of consumers and wholesalers outlet), $\rho_{31}$ (correlation between the choice of collectors and wholesalers outlet) are negative and statistically significant at $5 \%$ significance level; $\rho_{42}$ (correlation between the choice of cooperatives and consumers outlet) and $\rho_{43}$ (correlation between the choice of cooperatives and collectors outlet) are negative and statistically significant at $1 \%$ significance level; and $\rho_{32}$ (correlation between the choice of collectors and consumers outlet) are positive and statistically significant at $1 \%$ level. This result indicates that farmers selling their tef produce to the wholesaler outlets are less likely to deliver to consumers and collectors' outlets. Similarly, those farmers marketing tef to the cooperative outlet are less likely to deliver to consumers and collectors market outlets (Table 10).

The simulation results also indicate that the marginal success probability for each equation (outlet choice decision) is reported below. The likelihood of choosing collector outlet is relatively low (39.1\%) as compared to the probability of choosing consumer outlet (41.6\%), cooperative outlet $(51.1 \%)$ and wholesalers' outlet (64.4). This is an indicator that wholesaler is the most likely chosen market outlet by farmers and the low capacity of collector outlet to purchase more tef produce at a time and the limited capacity of collector outlet. The joint probabilities of success or failure of choosing four outlets suggests that the likely of households to jointly choose the four outlets is low. The likelihood of households to jointly choose the four outlets was $4.1 \%$ which is relatively lower compared to their failure to jointly choose them (5.1\%). The result in Table 10, indicated that out of explanatory variables used in the multivariate probit model, educational level of household head, household size (adult equivalent), livestock owned (TLU), equines owned (TLU), size of land under tef production, distance from the nearest market, and current market price of tef were found to significantly affect the market outlet choice behavior of tef producers.

Education level of the household head: Education level of the household head has positive and significant effect in choosing wholesaler and cooperative outlet at $1 \%$ and $5 \%$ probability level, respectively. In addition, education level of the household head has negative relationship with the likelihood of choosing consumer and collector outlet at $1 \%$ and $5 \%$ level of significance, respectively. The positive relationship between education level and selling to wholesaler and cooperative outlets, and the negative relationship between education level and selling to consumer and collector outlets shows the fact that being educated enhances the capability of farmers in making informed decisions with regard to the choice of tef marketing outlet to sell their tef produce based on the benefit they obtain. These results are in line with the findings of [18] which found that by making informed decisions educated farmers choose the best market outlets to sale their farm produce.

Household size: Household size has positive and significant relation with the likelihood of choosing wholesalers outlet at 5\% significance level, and negative and significant relation with the likelihood of choosing consumer and collector outlets at 5\% significant level. This result indicates that, having more household size positively correlate with the likely of choosing wholesalers outlet and has negative relation with likely of choosing consumer and collector outlets. This finding is consistent with the finding of [11] which found that having large family size was a better for delivering output to the final market outlet.

Size of land under tef production: The likelihood of choosing wholesaler and cooperative market outlet was positively and significantly related with the size of land allocated for tef production at $1 \%$ and $5 \%$ levels of significance, respectively. The result indicated that those households who allocated large size of land for tef production would produce more output and they likely to sell to wholesaler and cooperative outlets. The result is consistent with the findings of [12] who found an increase in land allocated increases farmers' likelihood of choosing wholesaler outlet than consumers outlet.

Table 10. Multivariate probit estimations of tef producers' market outlet choices.

\begin{tabular}{|c|c|c|c|c|}
\hline Variables & Wholesalers & Consumers & Collectors & Cooperatives \\
\hline Sex of household & $-0.232(0.298)$ & $-0.063(0.253)$ & $-0.152(0.255)$ & $-0.023(0.279)$ \\
\hline Education level & $0.166^{* * *}(0.050)$ & $-0.104 * * *(0.036)$ & $-0.088^{* *}(0.036)$ & $0.095 * *(0.038)$ \\
\hline Household size & $0.199 * *(0.089)$ & $-0.155 * *(0.067)$ & $-0.143 * *(0.066)$ & $0.018(0.071)$ \\
\hline Farming experience & $-0.003(0.021)$ & $-0.006(0.016)$ & $0.007(0.015)$ & $0.005(0.016)$ \\
\hline Livestock ownership & $0.049(0.075)$ & $0.065(0.060)$ & $0.038(0.060)$ & $0.117 *(0.065)$ \\
\hline Ownership of equine & $0.366^{*}(0.188)$ & $0.006(0.140)$ & $0.051(0.139)$ & $0.097(0.148)$ \\
\hline Land area under of tef & $0.831 * * *(0.321)$ & $0.285(0.243)$ & $-0.087(0.243)$ & $0.563 * *(0.267)$ \\
\hline Frequency of extension & $-0.013(0.035)$ & $-0.023(0.026)$ & $0.011(0.025)$ & $0.022(0.027)$ \\
\hline Non/off-farm income & $-0.029(0.023)$ & $0.001(0.019)$ & $0.016(0.019)$ & $0.014(0.021)$ \\
\hline
\end{tabular}




\begin{tabular}{|c|c|c|c|c|}
\hline Variables & Wholesalers & Consumers & Collectors & Cooperatives \\
\hline Current prices of tef & $0.793(0.624)$ & $-1.191 * *(0.477)$ & $-1.156^{* *}(0.481)$ & $-0.229(0.512)$ \\
\hline Constant & $-2.872 * *(1.299)$ & $2.233 * *(0.964)$ & $1.811 *(0.972)$ & $-1.099(1.055)$ \\
\hline Predicted probability & 0.644 & 0.416 & 0.391 & 0.511 \\
\hline Joint probability success & & & 0.041 & \\
\hline Joint probability of failure & & & 0.051 & \\
\hline Number of draws (SML, \# draws) & & & 100 & \\
\hline Number of observations & & & 210 & \\
\hline Wald chi ${ }^{2}(44)$ & & & 177.63 & \\
\hline Prob $>$ chi $^{2}$ & & & 0.0000 & \\
\hline
\end{tabular}

Estimated correlation matrix

\begin{tabular}{|c|c|c|c|c|}
\hline & $\rho_{1}$ & $\rho_{2}$ & $\rho_{3}$ & $\rho_{4}$ \\
\hline$\rho_{1}$ & 1.00 & & & \\
\hline$\rho_{2}$ & $-0.344 * *(0.142)$ & 1.00 & & \\
\hline$\rho_{3}$ & $-0.335 * *(0.147)$ & $0.527 * * *(0.095)$ & 1.00 & \\
\hline$\rho_{4}$ & $-0.224(0.168)$ & $-0.448 * * *(0.114)$ & $-0.330 * * *(0.120)$ & 1.00 \\
\hline
\end{tabular}

Likelihood ratio test of $\rho_{21}=\rho_{31}=\rho_{41}=\rho_{32}=\rho_{42}=\rho_{43}=0$

$\operatorname{chi}^{2}(6)=45.61$ Prob $>$ chi $^{2}=0.0000$

Source: Own computation from survey result, 2017

Note: Coefficient and standard errors in the parentheses

Symbols: $* * *, * *$ and $*$ indicates significant at $1 \%, 5 \%$ and $10 \%$ levels, respectively.

Equines owned: Ownership of means of transport (equines) measured in TLU has positively and significantly related with the likelihood of choosing wholesaler outlet at $10 \%$ significance level. The result depicts that having equines positively correlate to the likely of choosing wholesalers outlet, due to the fact that those households who have equine transport go distant market in order to sale their tef produce to the market that offer better price than other outlets having low price. Since there is no vehicle transport service in the rural study area, ownership of means of transport (equine) offers a greater opportunity in market outlet choices. This result was similar with the finding of [10] who found that number of equines owned has positive and significant influence on probability of choosing the best outlets to sell outputs produced and to achieve higher price.

Livestock owned: Number of livestock owned measured in TLU has significant and positive relationship with the likelihood of choosing cooperative outlet at $10 \%$ significance level. This is due to the positive impact of livestock on the tef production by providing cash to purchase improved seed and in-organic fertilizer for tef production, and oxen serve as a traction power this increases the amount of tef produced and the management of livestock makes the household to select nearby market outlet that benefits them. Thus, the result revealed that those households producing high amount of tef output are more likely selling their tef produce to cooperatives outlet.

Distance from the nearest market: Distance from the nearest market is negatively and significantly associated with likelihood of farmers selling to wholesalers and cooperatives outlet at $5 \%$ and $10 \%$ level of significance, respectively; and positively associated with likelihood of selling to consumer and collectors at $5 \%$ level of significance. The implication of this finding is that households located far away from the nearest market faces difficulty in delivering tef produce to wholesaler and cooperative outlet and the farmers sold to consumer collectors' outlet due lack of transport service in the study area and to reduce transaction cost of delivering tef produce to the market. This result is supported by the findings of [9] who found that market distance has negative relationship with wholesalers and positively related with collectors' outlet.

Current market prices of tef: Current price of tef is negatively and significantly associated with the likelihood of choosing consumer and collector outlets at 5\% level of significance. This implies that the market price of tef shows some fluctuation at market day and due to fear of consumer and collectors offer lower price for tef than other market outlet farmers are not likely to deliver to consumer and collectors' outlet. The survey result indicates that consumers and collectors in the study areas have a limited financial capacity and wants to purchase smaller quantity of tef at lower price, due to this farmer are less likely sell to consumer and collectors' outlet and tef producers prefer other market outlets having higher prices. This result is consistent with the findings of [9, 19] who found own product price negatively affect the likely of selling to consumer and collector outlets.

\section{Conclusion and Recommendations}

The study was aimed at identifying determinants of market outlet choices of tef producers in Dendi district of Oromia region, Central Ethiopia. The study was conducted with the specific objectives of identifying tef marketing channels and factors affecting market outlet choices of tef producers in the study area. Tef producers in the study area sold tef grain through different market outlet based on their choice. In the study areas there are four tef market outlets, the survey result indicated that $133(63.33 \%)$ of households sold their tef output to wholesalers whereas 81 (38.57\%), $87(41.43 \%)$ and $104(49.52 \%)$ of the sample households sold their tef output 
to collectors, consumers and cooperatives, respectively. Along this, six tef marketing channels through which tef produce flows to the final consumers are identified in the study areas.

The result of multivariate probit model revealed that the likelihood ratio test in the model is statistically significant at $1 \%$ significance level, implying choices of the four market outlets is interdependent. The probability of choosing wholesaler market outlet was significantly affected by education level of household head, household size, ownership of equine, land area allocated to tef production, and distance from the nearest market. The probability of choosing consumer market outlet was significantly affected by educational level of household head, household size, current market prices of tef and distance from the nearest market. The probability of choosing collector market outlet was significantly affected by education of household head, household size, distance from the nearest market and current market prices of tef. Likewise, the probability of choosing cooperative market outlet was significantly affected by educational level of household head, distance from the nearest market, livestock owned (TLU) and land area allocated to tef production.

The probability of choosing wholesalers market outlet is $64.4 \%$ whereas the probability of choosing consumers, collectors and cooperatives outlet is $41.6 \%, 39.1 \%$ and $51.1 \%$, respectively. This shows wholesalers is the most likely chosen market outlet while collectors outlet is less likely chosen. The joint probabilities of households to jointly choose the four market outlets is $4.1 \%$ which is lower than the likely of not choosing all outlet which is $5.1 \%$. The correlation between each pair of dependent variables implies that farmers selling tef grain to cooperative and wholesaler outlet are less likely to deliver to consumer and collector outlet.

From the findings of this study the following relevant recommendations are drawn. The multivariate probit model result showed that tef producers were influenced by different factors to choose appropriate market outlets to sell their tef produce. The finding suggests that an adjustment in each one of the significant variables can significantly influence the probability of choice of market outlets. Attending of formal education by household head is better in searching appropriate market outlets, thus the concerned authority should be able to increase the awareness of households about the importance of adult and formal education to choose appropriate market outlet in selling outputs.

Expanding equal accessibility of road infrastructures and availing transportation services needs government intervention to promote the effective marketing of tef through high price fetching outlet. Households who lives far from the nearest market without their own means of transport are unlikely to sell to wholesales outlet, indicating the importance of adequate road facilities, transportation services and equines in providing options for marketing tef produce to attain a better price. Since, traders want to operate in areas of good road facilities and better transport services, households tend to minimize transaction costs by selling to collector outlet who typically offer low prices. Therefore, this study recommends that improving of existing road infrastructure and creating conducive environment for transport service would reduce transportation costs as well as time spent to reach the market and enhance farmers to sell their produce to the outlet that results higher returns.

The study also points that increasing of size of land allocated to tef production positively related with the likely selling to wholesales and cooperative outlet. Here producing more output encourages the farmers to choose appropriate market outlets, thus concerned body has to advice farmers to efficiently utilize land resources. Livestock ownership has positive effect on tef production and selection better market outlets; thus, efforts are required in improving number of livestock ownership. Actual market price of tef is also an important factor to influence choice of appropriate market outlets. Increasing production alone is not enough without reasonable selling price, offering better price for tef produce can inspire farmers to produce more and in selling through the best market outlets. Hence, delivering of updated market price information is essential for farmers to make informed decision in marketing of tef output.

\section{Acknowledgements}

The authors are indebted to Dr. Temesgen Desalegn; Tadele Mamo; Wudneh Getahun; and Takele Mebratu for their encouragement and support. We appreciate all the enumerators; Dendi district agricultural office staff and all the respondents who took part in the study too.

\section{References}

[1] ATA (Agricultural Transformation Agency). 2017. Agricultural Transformation Agenda. Annual Report of 201617. Addis Ababa, Ethiopia.

[2] FAO (Food and Agricultural Organization of the United Nations). 2015. Ethiopia Country Highlights on Irrigation Market Brief. UNFAO, Rome, Italy.

[3] CSA (Central Statistical Agency). 2016. Agricultural Sample Survey 2015/2016 (2008 E. C): Report on area and production of major crops, volume-I. Addis Ababa, Ethiopia.

[4] Vavilov, N. I. 1951. The Origin, Variation, Immunity and Breeding of Cultivated Plants. Translated from the Russian by K. S. Chester. Ronal Press Co, 13 (1/6): New York, USA.

[5] Minten, B., Seneshaw Tamru, Ermias Engida, and Tadesse Kuma. 2013. Ethiopia's Value Chains on the Move: The Case of Tef. Working Paper 52. Ethiopia Strategy Support Program, April 2013. Ethiopia.

[6] Bekabil Fufa, Befikadu Behute, Rupert, S. and Tareke Berhe. 2011. Strengthening the tef value chain in Ethiopia. Agricultural Transformation Agency. Addis Ababa, Ethiopia.

[7] Barrett, C. B. 2008. Smallholder market participation: Concepts and evidence from Eastern and Southern Africa. Food Policy, 33 (2008): 299-317. 
[8] Wickramasinghe, U. and Weinberger, K. 2013. Smallholder Market Participation and Production Specialization: Evolution of thinking, issues and policies. Working Paper No. 107. Center for Alleviation of Poverty through Sustainable Agriculture (CAPSA). Jalan Merdeka 145, Bogor 16111, Indonesia.

[9] Addisu Hailu. 2016. Value chain analysis of vegetables: The case of Ejere district, West Shoa Zone, Oromia region, Ethiopia. MSc Thesis, Haramaya University, Haramaya, Ethiopia.

[10] Shewaye Abera. 2016. Econometric analysis of factors affecting haricot bean market outlet choices in Misrak Badawacho district, Ethiopia. International Journal of Research Studies in Agricultural Sciences, 2 (9): 6-12.

[11] Takele Honja, Endrias Geta and Amsalu Mitiku. 2017. Determinants of Market Outlet Choice of the Smallholder Mango Producers: The Case of Boloso Bombe Woreda, Wolaita Zone, Southern Ethiopia: A Multivariate Probit Approach. Global Journal of Science Frontier Research, 17 (2): 23-29.

[12] Oliyad Sori, Mengistu Ketema and Mohammed Aman. 2017. Factors Affecting Market Outlet Choice of Groundnut Producers in Digga District of Oromia State, Ethiopia. Journal of Economics and Sustainable Development, 8 (17): 61-68.
[13] DDAO (Dendi District Agriculture Office). 2017. Annual report of Dendi district, Oromia region, Ethiopia.

[14] Yamane, T. 1967. Statistics: An Introductory Analysis, $2^{\text {nd }}$ Edition. Harper \& Row, Publisher, New York. pp. 919.

[15] Belderbos, R., Carree, M., Diederen, B., Lokshin, B. and Veugelers, R. 2004. Heterogeneity in R\&D cooperation strategies. International Journal of Industrial Organization, 22 (2004): 1237-1263.

[16] Cappellari, L. and Jenkins, S. P. 2003. Multivariate probit regression using simulated maximum likelihood. Stata Journal, 3 (3): 278-294.

[17] Kohls, R. L. and Uhl, J. N. 1985. Marketing of Agricultural Product. Fifth Edition. McMillian Publishing Company, New York, USA.

[18] Chala Hailu and Chalchisa Fana. 2017. Determinants of Market Outlet Choice for Major Vegetables Crop: Evidence from Smallholder Farmers' of Ambo and Toke-Kutaye Districts, West Shewa, Ethiopia. International Journal of Agricultural Marketing, 4 (2): 161-169.

[19] Sultan Usman. 2016. Analysis of Wheat Value Chain: The case of Sinana district, Bale Zone, Oromia region, Ethiopia. Thesis Haramaya University, Haramaya, Ethiopia. 